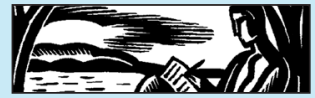

\title{
Coming to One's Senses: Diaries and the Materiality of Mourning in Sophie Calle's Rachel, Monique
}

\author{
Sonia Wilson
}

University of Sydney

\begin{abstract}
After a woman's death certain material objects, commonly referred to as 'personal effects,' remain. Diaries are sometimes among these. This essay focuses on the trajectory taken by one mother's diaries in particular, examining the shifts in meaning effected by the circumstances in which they are passed on to the daughter and by their subsequent emergence into the daughter's work in 2012. Since her mother's death in 2006, the internationally established writer, photographer and installation artist Sophie Calle has staged a series of installations consisting of material markers of mourning. The diaries enter this installative series in 2012. This essay investigates how Calle's engagement with the diaries dialogues with existing cultural representations of The Mother's Diaries and explores the effects of their display on conventions of mourning and exhibiting practices.
\end{abstract}

Keywords: diary, mourning, the sensory, Sophie Calle

In the past thirty years or so, a growing scholarly interest in the materiality of mourning in everyday contemporary life has emerged. ${ }^{1}$ Focussing on the material remnants of the deceased, the belongings of the dead and those artefacts crafted either pre or post death as objects of mourning, this scholarship mounts a considerable challenge to the still widely held notion, often derived from comparisons with the highly codified and intricate rituals of Victorian mourning practices or the equally elaborate funeral rites of non-Western cultures, that death and dying in contemporary Western society is characterised by a paucity of ritual and representation. 
In 2001, in their sustained investigation into the ways in which, as they put it "the dead and the living find proximity via material objects and places" Hallam and Hockey point out that while differentiated death spaces such as crematoria and graveyards continue to exist, their landscape is changing (6). Scattered among the more traditional bouquets of flowers and the mourning statuary of guardian angels and memorial vases, one now finds personal objects that the bereaved associate with the deceased: bottles of beer, cigarettes, soft toys, and tinsel at Christmas. The increasing hybridity and eclecticism of these markers of mourning trigger, they observe, not only meditative contemplation on the part of the visitor, but also visual interest. In order to illustrate this point, they point to a photograph of a baby's grave taken in a US cemetery. ${ }^{2}$ Opposite a metal cross at the head of the grave, a sign has been hung on which one reads the words "Visitors welcome. Photos allow". As Hallam and Hockey observe, in this instance, the grave site "enter[s] the territory of site-specific art" (210).

In what follows, I am interested in a series of art installations which enter the territory of personal mourning. Sophie Calle is an internationally established writer, photographer and conceptual artist with a reputation for staging exhibitions in which she draws on elements of her personal life. Calle's mother died in 2006. In 2007, Calle created an installation entitled "Pas pu saisir la mort" 3 at the Venice Biennale. Since then, she has staged a further three installations ${ }^{4}$ and produced what I shall refer to as a photo book (2012), all of which centre on her mother's death and dying. Given this consistency of focus, and the fact that certain objects remain a constant throughout, resurfacing in one exhibitive context after another, the installations and the photo book can be seen as composing a sensorial and semiotic network that unfolds in time and space across a number of different contexts of display-the gallery, the page, the church.

Other scholars before me have already situated this particular exhibitive impulse of Calle's with respect to wider cultural shifts in the public articulation of death and dying. ${ }^{5}$ As will become apparent in the course of this essay, I am deeply indebted to their work. However, my focus differs from theirs. To enter Calle's installative space is to participate in both the history of Western practices of mourning and that of what one might loosely call the exhibitive space and its turn, in the last few decades, away from the white cube. ${ }^{6}$ I am interested in what happens to Calle's configuration of mourning and exhibitive conventions when one set of objects in particular enters it: the sixteen carnets (notebooks) that comprise the journal intime that Sophie's mother kept, on and off, for a period of almost twenty years. The carnets enter Calle's installative series belatedly, making 
their public debut in 2012 in two different contexts of display almost simultaneously. Between July 8 and July 28 they constitute part of the installation Rachel, Monique staged in the Cloître des Célestins as part of the Avignon festival. From July 5 of the same year, photographic reproductions of the diary's pages and typed transcriptions of selected extracts began to circulate in Calle's photo book.

To date, the emergence of the carnets into the installative space and the material forms in which they do so has received relatively little critical attention. This is in part due to the delayed nature of their entry into the installative series. It is however, also a function of the tremendous affective clout exercised by the one element of the installative series that has remained a constant throughout: the looping video footage entitled Pas pu saisir la mort in which Monique, Calle's mother, lies motionless in bed, her eyes closed. At the beginning of the eleven minute video Monique is alive. By the end she is dead. First shown on loop at the Venice Biennale in 2007, this footage has been shown in every subsequent installation of which the mother is the focus. When the diaries enter the installative series dedicated to the mother, emerging in the Cloitre des Célestins in Avignon in 2012, they are displayed within a space defined not merely by the inner architecture of the Cloitre and its history as a cultural site, but also by the other objects carefully arranged by Calle within it and which, by 2012, have their own history of display. The video footage is one of these and I shall return to it shortly.

To my mind, it is precisely the delayed nature of the diaries' entry into the installative series that marks them as objects of particular interest. The fact that they remain for longer in the private space of Calle's home sets them apart from the other objects with which Calle is left after her mother's death and that enter her installations much earlier, even as the diaries' display with these objects designates them as, like them, the remnants of a life. How the forms in which the diaries are displayed engages with these other objects and with the sites of display in question is one part of what I wish to investigate in what follows. The other relates to the diary's status as both personal possession and cultural practice. Calle's display of her mother's diaries constitutes an auto/biographical act. This act marks a significant point in her own process of mourning, in the ongoing construction of her $x u v r e$, in the posthumous afterlife of her mother and in the social biography of the diary notebooks. ${ }^{7}$ However, her performance of this act, and our participation within it as readers and installation visitors, also contributes to, and is shaped by, the wider network of cultural representations of the encounter of the bereaved adult child with the mother's diaries. How it does so is the second question that I wish to pursue in what follows. 
The frequency with which the mother's diaries surface in both fiction and autobiography over the course of the twentieth century suggests that they constitute a source of particular fascination, not only diegetically for the bereaved adult child, but also for the wider reading and film-going public. Consider two examples, one fictional, the other autobiographical. In the opening scenes of the commercially successful film The Bridges of Madison County (1995) an adult son and daughter are handed the contents of their mother's safe deposit box, in which they discover a brown envelope containing photographs neither sibling has ever seen before, a letter from a lover they never knew their mother had, and the key to a large wooden trunk in the mother's bedroom. In the latter, they discover three thick notebooks, on the white covers of which the single word Jour$n a l$ is embossed in gold. The camera then cuts to the brother and sister, seated at their mother's kitchen table. The daughter reads aloud from the first notebook. Her voice segues into her mother's as the kitchen transforms visually into the kitchen of their childhood, initiating the extended flash-back that recounts the mother's adulterous and passionate relationship with a National Geographic photographer. Here, the role the diaries play with respect to diegesis is a familiar one: their discovery and reading provides the narrative framework for the story that follows, heightening its interest by injecting it with connotations of authenticity.

Also found in a safe deposit box after her death, Ingmar Bergman's mother's diaries are an insistent presence in the last chapter of his autobiography. Bergman recounts having watched as, following the diaries' discovery, his father sat down every day, diaries in hand, "a strong magnifying glass" trained on the "microscopic, partly coded writings" (285). Once again, what emerges from the diaries is a story of adulterous desire, combined this time with that of great unhappiness in marriage. At the end of the chapter, it is Ingmar himself who takes up the diaries in a bid to understand the riddle of family relations. He is forced to conclude, his diary reading and flashes of insight notwithstanding, that "the mystery remains unsolved" (289).

In both the fictional film and the autobiography, the story of the diaries is subsumed within a wider plot-one that might be loosely titled Mother as Mystery. Both narratives speak to the complex web of fear and fantasy that attaches to the mother's sexual desire. In both cases, adult siblings look to the diary for truths that, they assume, must lie dormant within it. In neither account do we find out what happens to the diary itself; as a result of reading it, the adult daughter divorces her husband and the son vows to renew his efforts to make his marriage work; the diary disappears altogether. It is of narrative interest only insofar as its contents have not yet been extracted from it. 
What however I would like to retain from Bergman's narrative, is not the story of the mother's infidelity, nor Bergman's positioning of the diary as hermeneutical key to his own anguish, but the scene of the son watching the father who looks at the diary pages through a magnifying glass. Interestingly, in later years, Bergman son takes up a magnifying glass of his own, using it to scrutinise not the pages of the diary, but his mother's face on old family photographs. After his father's death, he appropriates the family albums, and makes from them a small film entitled "Karin's Face."

Unlike the mothers that emerge from the stories above, Monique Calle comfortably assumed her status as desiring subject both privately and publicly in matters sexual, intellectual and affective for the duration of her adult life. An attaché de presse in twentieth-century Paris who moved in intellectual and artistic circles, she had three husbands and a string of lovers. Nevertheless there are some similarities between Calle's reading of her mother's diaries, Bergman's account and the fictional film scenario. In all three cases, it is to the adult daughter rather than the son that the mother's diaries are left. ${ }^{8}$ As in the film, the mother's diaries are bequeathed to Calle in a box that also contains photographs. Like Bergman, Sophie Calle is a manipulator of both words and images. However, as a conceptual artist, she also draws on material objects as a means of manipulating space. Indeed, she manipulates words and images as material objects: the word 'souci', for example ${ }^{9}$ the last to be spoken by Calle's mother before she died, appears in every installation dedicated to Monique, spelled in materials that carry clear cultural associations with mourning or death, ranging from porcelain and hair (2010) to flowers and, in 2014 in New York, dead butterflies. Calle's long experience of exploring the relationship between words and the sensory qualities afforded by the material means that give them shape suggests that her treatment of her mother's diaries will, unlike either the adult siblings in the film, or Bergman junior's, extend beyond merely extracting sexual revelations or explanatory keys to the past from them.

Given that as far as I have been able to ascertain, the photo book was first made available on July 5 2012, three days before the opening of the installation at the Festival d'Avignon, I shall begin my analysis with it. Calle introduces her mother's diaries into the book by way of the following short text:

Quelques jours avant de perdre conscience, ma mère m'a demandé d'emporter chez moi le carton qui contenait ses albums de photos et ses journaux intimes. 
Seize carnets datés 1981, 1984, 1985, 1986, 1987, 1988, 1990, 1991, 1992, 1993, 1994, 1995, 1996, 1997, 1999, 2000.

Elle a choisi de ne pas les détruire. Ma mère n'était pas dupe de ce qui pourrait arriver si elle me les abandonnait.

Sinon je ne me serais pas permis. ${ }^{10}$

In the days leading up to death, and as part of the preparation for it, the mother asks the daughter to take her diaries. In a Skype interview conducted in March 2014, Calle contextualises her mother's request further: "We knew she was going to die, so we were not hiding the fact. We started to dig through her things. I asked her who I should give this or that to, like her jewellery. It was during that discussion that she said, 'Take the diaries, take them all now" (Julavits 2014).

As Hallam and Hockey have observed, the particular point in the dying process at which objects are circulated and the spatial context in which their transaction is negotiated are determining factors in shaping their meaning (13-14). Here, the diaries and photographs change hands in the context of a discussion which includes the mother's jewellery. That these objects should be singled out as the stuff of what will be one of the last discussions that mother and daughter will ever have, that the question of their ownership should arise and be resolved not in the formal context of will-making, but in the far more intimate setting of a bedside chat conducted in the shared knowledge that the mother is to die soon, draws them together, investing them with an affective significance that takes precedence over both their financial and their immediate use value. Neither run-of-the-mill household items such as shampoo bottles or tea towels, whose future rarely constitutes a topic of discussion at all let alone in the days leading up to death, nor are they of sufficient material and commercial consequence to be transacted in a will.

To consider Monique's diaries and photograph albums in the same light as her jewellery is to be reminded of the function performed by all three as tools in what one might call an attention to, or working on and with, various aspects of selfhood. A cursory glance at the extracts selected for publication in the photo book confirms that Monique drew upon diary writing as, among other things, a means of regulating her emotional equilibrium. She often wrote in the wake of emotionally distressing events - the death of her own mother for example, or the diagnosis of breast cancer. Like the donning of a necklace or a ring, the writing of the diaries constituted one of the means by which Monique prepared, in private, her social self. As embodiments of Monique's attention to her person, and by dint of the regularity with which such attention was exercised, these objects became during her lifetime the loci of small, everyday acts: the necklace clasp was fastened and unfastened; the diary carnet opened, 
blank pages smoothed down; photographs turned over and adhesive substance applied to their backs; the album hefted up and rested on two sets of knees. Touched often and regularly by Monique, these objects point back to her body, bearing the traces of it in the form of tiny scratches in metal or paper. The size and shape of the ring echoes that of the finger that once wore it; the heaviness of the pen strokes that form the writing of the diary point back to the body of labour ${ }^{11}$ of the diary writer; the photographs are not only products of a moment in time that brought together, in space, Monique's body, that of the photographer and that of the camera, but also bear witness to her handling of them in the form of creases or torn corners.

However, while Calle's account of the deathbed transaction between mother and daughter implies that diary notebooks, photograph albums and jewellery are of similar significance, what she does with them in the years following Monique's death suggests otherwise. The second half of the photo book consists of photographs taken of Calle's 2010 installation held at the Palais de Tokyo. These installation shots make it clear that Calle did not wait until 2012 to engage with the other objects bequeathed her at the same time, and by the same means, as the diaries. A copy of the obituary published in Libération in March 2006 and displayed in the 2010 installation is reproduced in the second half of the photo book: it shows a black and white photograph of Monique, pulling a comical face from under a floppy hat, that one recognises from the first half of the book as one of the photographs from Monique's albums. Even more significantly, two items of jewellery, a ring and a necklace, also surface within the second half of the book as the subject of their own photographic sequence. Positioned in a horizontal line across the wall of the Palais de Tokyo, arranged to ensure a left to right viewing and accompanied by text, this visual sequence articulates a narrative of burial.

In the first set of two photographs, a diamond ring and what looks like a pearl and ruby necklace lie on the edge of a ship's open porthole; the edges of the porthole frame ocean, glaciers, ice banks and sky. In the next set of three photographs, a black and white photograph of Monique smiling broadly, face straight to camera, has been added to the objects. Closing the sequence are a further two photographs: the ring, the necklace and the photographs have now shifted from ship to land. In the first photograph, the objects lie partially buried in snow. Monique's photographed face is still clearly visible from under the slant of a rock. The second photograph shows only a frozen stretch of Arctic ground, covered in snow and littered with rocks; we are unable to identify the rock we saw in the previous paragraph. The text that accompanies this visual sequence does three things: it casts the jewellery's appearance on 


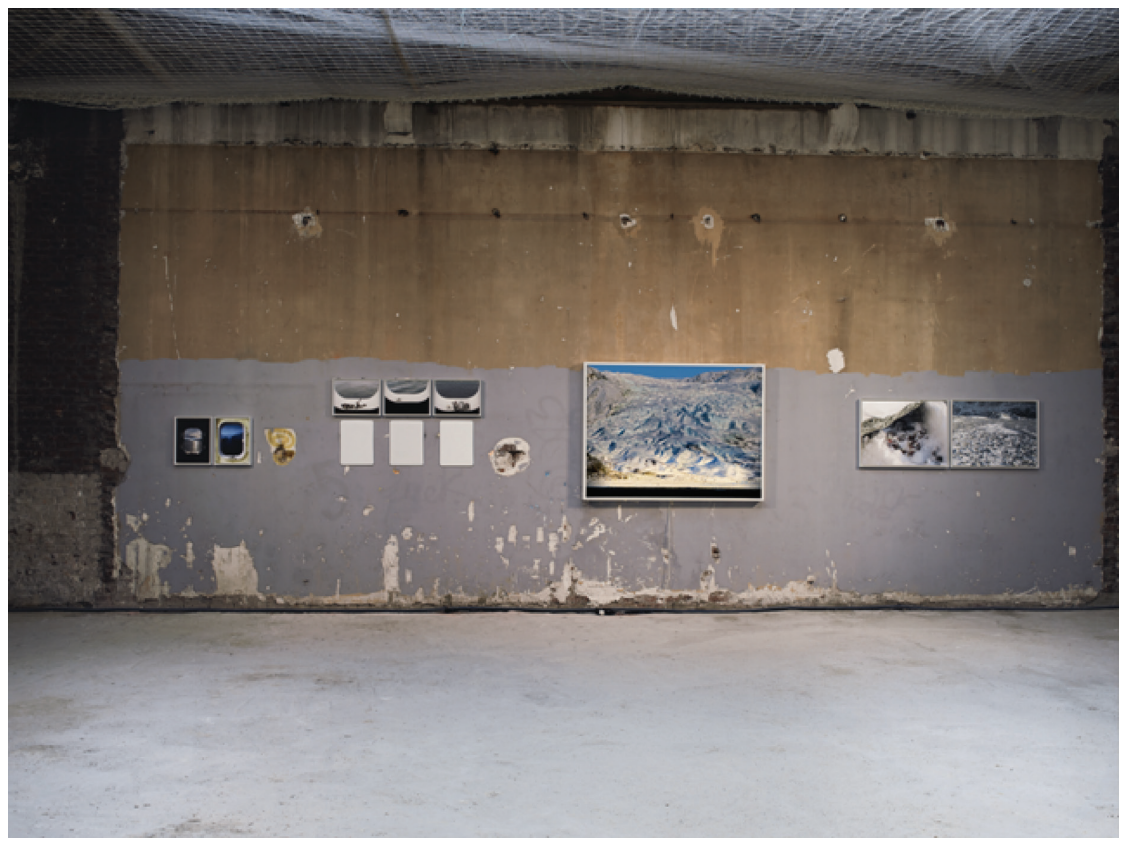

(C) Sophie Calle/Éditions Xavier Barral ${ }^{12}$

the port-hole ledge and its disappearance under the snow as a burial enacted by Sophie herself; it positions this act of burial as a means of fulfilling a desire articulated by the mother, but still unaccomplished by her at the time of death and lastly, in its careful juxtaposition of sentences, it conflates the photographic portrait, the ring and the necklace with the body of the mother:

Ma mère avait toujours projeté d'aller un jour au pôle Nord. Elle est morte il y a deux ans sans accomplir ce rêve. [...] Invitée à naviguer dans l'Arctique, j'ai accepté pour elle. Pour l'emmener. Je suis descendue sur la grève. J'ai choisi une pierre et j'ai enseveli le portrait, le collier et la bague. Ainsi ma mère est arrivée dans le Grand Nord. (Calle n.p.) $)^{13}$

Note that in both the case of the photographic portrait of Monique in a floppy hat and that of the jewellery, what is displayed is not the object itself, but its role in an act of mourning already performed by the daughter outside the installative space. Composing the obituary, selecting the photograph to appear with it, contacting the newspaper, discussing dates, 
were part of the many small acts of seeing and saying in which the daughter was involved in the immediate aftermath of her mother's death. As for the ring and necklace, as Calle's intersemiotic narrative unfolds, it becomes increasingly clear why they are visually, but not materially, available in the Palais de Tokyo. By 2010, they have already moved on; indeed, it is the process of their movement through and out of Calle's hands that is displayed here as narrative. In both cases, what is shown is the work performed on and by these objects in the mourning process. This work triggers, and depends upon, the mobility of the objects as they shift from one spatial context to another. By stark contrast, the diary notebooks remain remarkably static in the years following Monique's death.

At one level, this is not surprising. The difference between pieces of jewellery, photographs and diary notebooks is, of course, that whereas the former two sets of objects are made for display, crafted in ways that catch and hold the eye, the diary is not. Worse: the very ways in which diary writing functions as a practice necessitates that it not stray from the private context of its keeping. To circulate the diaries in public is to risk compromising the work of preparation and composition of the social self that its keeping performed for Monique while she was alive. This makes their display in any shape or form a very fraught prospect indeed. The careful wording and elisions of the second half of the short text which introduces the diaries into the photo book suggests as much. As Calle shifts from recounting the means by which she came by the diaries to broaching-obliquely-the matter of their publication, the precision of the first two sentences-in which the circumstances of the diaries' transaction are briefly and matter-of-factly stated, and numeric details provided-gives way to a carefully cultivated imprecision: "Elle a choisi de ne pas les détruire. Ma mère n'était pas dupe de ce qui pourrait arriver si elle me les abandonnait. Sinon je ne me serais pas permis" (Calle n.p.). ${ }^{14}$ Calle's act of publication is not enunciated, but merely alluded to as "ce qui pourrait arriver" before being elided altogether as the last sentence comes to an abrupt halt: "Sinon je ne me serais pas permis." What Sophie would otherwise never have allowed herself to do is made clear by the enunciative situation of the text; it is not articulated by it.

This performance of circumspection with respect to the act of display distances the diary notebooks from photograph albums and jewellery, and aligns them instead with the only other installative piece whose display is similarly mediated by a show of carefulness: the video footage in which Monique lies dying. In every context in which it has been shown, the video has appeared with the following short text. This text also inaugurates the photo book as a whole. 
Ma mère aimait qu'on parle d'elle. Sa vie n'apparaît pas dans mon travail. Ça l'agaçait. Quand j'ai posé ma caméra au pied du lit dans lequel elle agonisait, parce que je craignais qu'elle n'expire en mon absence, alors que je voulais être là, entendre son dernier mot, elle s'est exclamée "Enfin." (Calle n.p. $)^{15}$

Like the handing over of the diaries, the filming of the mother is represented as part of the preparations for death: the daughter sets up the camera in dreaded anticipation of her mother's passing. The site and the function of these transactions invests the mother-daughter exchange with the authority of death. For Calle to refer to it at the entry to an exhibition in which the video is shown, or as preface to the display of the diary's open pages, is not merely to evoke the mother's words, but to invoke them. Yet one notes that the short text concerning the setting up of the camera is, in its own way, as elusive as the second half of the text that prefaces publication of the diaries. What exactly the mother's word authorises is not clear. At work in this text is a careful sequencing of sentences that performs much the same function as the ellipses and circumlocution in the brief account of the mother's diaries. A link is implied, but not stated, between Calle's opening statements concerning her mother's annoyance at not featuring in her daughter's work, and the account of setting up the camera that follows. This allows-encourages even-the reader to infer that the mother's response to the arrival of the camera at her bedside is an indication of both her delight at appearing in front of her daughter's lens and her willingness that the video footage thus produced be shown in a public, rather than a domestic, context.

Both short texts have been interpreted by critics and reviewers as an attempt on Calle's part to "defend" or justify the exhibitive act. ${ }^{16}$ The question to my mind is not whether these accounts of deathbed transactions succeed or not as a means of making a convincing case for display, but rather what the elaboration of this rhetoric of appeal and circumspection does with respect to the expository and/or reading situation into which we subsequently enter. In their apparent efforts to curtail or offset the risk of exposition turning into exposure, these texts merely reinforce it. It is precisely because Calle links both the making of the video and the passing on of the diaries so explicitly, so clearly, to her mother's deathbed desires, that the silence concerning their shift from the confines of the home to the public art circuit is made readable. In the process of recounting the passing on of the diaries, Calle makes it clear that the mother's request was made in the course of 'dig[ging] through her things' mere days before her death; this suggests that Monique had neither the time nor perhaps the inclination to revise the diary that she 
had stopped writing six years before. Even as Calle situates display of the diaries with respect to the mother's words, she further reinforces their unpreparedness for the public domain. Similarly, her explanation of the reason for which she set up the video camera-she fears that her mother will die while she is out of the room-reinforces the imminence of the end. At such an advanced state in the process of dying, Monique can no more compose her facial features than she can edit her diary writing. At the point in time at which they are made available to the daughter, neither Monique's face nor her diary pages are camera ready. This invests both with connotations of vulnerability.

That this triggers a great deal of discomfort on the part of the viewer of the video is made amply clear by English academic Emma Wilson, who has written candidly and eloquently of her thoughts when travelling from England to Venice to see the 2007 installation at which the video was shown for the first time:

Imagining the installation before arriving in Venice I thought in terms of obscenity, of the visceral horror of an artist putting on show and exposing intimate moments of her mother's life. (Wilson 2011: 177).

Apprehension is almost palpable here. Significantly however, Wilson only evokes the horror that she imagines, pre-arrival, will be an integral part of her viewing experience in order to emphasise the entirely unexpected effects of the expository situation once she steps into it. Here is her full description of what she sees, and what seeing it does to her:

[Monique] is motionless for the time of the video [...] The screen and its deathbed images seem to transform the room into a secular chapel or the scene of a wake. The images transfix the viewer. [...] The tranquillity of the images is disquieting. Monique is still and the camera is still. Moments of the film stretch our sense of the distinction between still photography and moving film. We stare as if at Monique's still, dead, effigy, as if at a still frame, and viscerally then feel the intrusion of Sophie's hand as she reaches in to feel Monique's pulse and in so doing to remind us that the still woman we view is dying perhaps but not yet dead. We are led to know that Monique dies before our eyes in this stream of her daughter's images and that she is dead at its end. Monique's state and composure seem constant, however, through the footage. (Wilson 2011: 167).

Viewing does not eradicate the horror one feels when one first learns that Calle has centred an installation around a video of her mother dying. Instead, it reconfigures it, localising it at a particular point in the viewing process, sharpening its contours and intensifying it. Wilson does not sit in 
shock for the duration of the video; shock is delivered. It derives, as Wilson makes beautifully clear, from the contrast between stillness and movement. Despite the fact that we know both that we are watching a video, and that the woman we see in it will die in the course of its unfolding, the stillness of the body and of the camera that films it lulls us into the visual illusion that the image itself is frozen and that what we see is not a film, but a photograph. This illusion is further enhanced by the visual rhetoric that shapes the image and therefore our viewing of it. The composition, framing and light of the opening frames of the video draw, rather pointedly, on the conventions of post-mortem photography. ${ }^{17}$ It is as much our familiarity with these visual conventions as Monique's stillness within the image that creates the illusion that Monique is, in fact, already dead. ${ }^{18}$ The familiarity of what we see momentarily takes precedence over what we know. The movement of the hand puts a stop to this: the passing of time is visibly introduced into the expository situation, and with it, narrative sequencing. With our re-entry into the expository situation of film, we realise that Monique was in fact not already dead-worse, that she has just died, and that, our prior knowledge that she was going to die notwithstanding, we have missed the moment of death.

As is apparent from Wilson's description, Sophie was in the end present when her mother died. As was a cousin and a nurse. Their physical proximity to Monique's body notwithstanding, they too appear to have missed the moment of death. The YouTube extract of the video enables us to catch a glimpse of the profile of the owner of the hand, looking up as if to consult someone off screen before reaching across again, this time on the other side of Monique's face, placing a second hand simultaneously on her chest. Another hand then enters the screen, and pauses, cupped backwards in front of Monique's mouth. What Calle discovers is that death doesn't show: it is neither visible, nor immediately palpable. What we see is the enactment of this discovery. What the video makes visually available is not then, as Sophie had hoped, the moment of death, but instead a performance of its non-showability.

Let us now return to Bergman's description of his father, sitting down every day with magnifying glass in one hand and his deceased wife's diaries in the other. Like Bergman senior, Calle draws on visual technology as a means of seeing what her own eyes may miss. The sad irony is that the more the father deciphers, the less he understands. The glass makes readable only Karin's unknowability. In not dissimilar fashion, Calle's camera registers not the moment of death, but a performance of its elusiveness. However, decoding loops and curls of handwriting and turning them into meaningful text is not the only thing that a magnifying glass affords. Nor can the manipulation of a camera lens be seen solely in terms of the 
images produced. This is made beautifully clear by Margaret Olin in the opening paragraph of her study Touching Photographs. She imagines $\mathrm{Mr}$ Fox Talbot, seated at his writing table in 1844, performing looking:

He holds a magnifying glass to a photograph, leans forward, raises the glass to his eye, and adjusts his position to focus on the portion of the photograph he has chosen. This gesture, ostensibly about photographic detail (a magnifying glass is an aid for seeing), is also about the way in which a photograph is handled, how intimately one can engage with it. (1)

Intimate engagement, its terms and conditions, and the pain and pleasure afforded by it is as much at stake in Bergman's handling of the magnifying glass and his wife's diaries as it is in Calle's manipulation of the camera with respect to her mother's body. Olin observes that while people mock tourists for their reliance on the camera, many of them "gesturing with cameras, actually seek encounters through their lenses". Visual technology, as Olin makes clear, does not get in the way of our encounter with objects or people, but is a constituent part of that encounter.

Three photographic stills from the video footage are placed at the centre of the photo book. In the first photograph, Monique lies, eyes closed, peacefully, head on pillow. In the second, we see a hand by Monique's face, positioned toward her neck, where one might find a pulse. In the third photograph, the same hand is placed before Monique's mouth. These photographs are preceded by selected pages and excerpts from Monique's diaries, interspersed with photographs from her albums. In terms of the sequencing of the elements with which they are published here, the photographic stills of the film occupy-with respect to the book as a whole-a very different position to that of the video in the 2007 installation. When reflecting on what is not shown by this installation, Wilson suggests that the shock of viewing is heightened by the omission of what led up to the moments of dying it represents. "We have," Wilson observes, "no countdown to the day of death or avowal of the obscenity of the decision on when to film and when the end was close (enough)". It is tempting to read the diary entries and photographs that precede the stills in the centre of the book as the missing countdown: after all, both diary pages and diary excerpts are arranged in chronological order, starting in 1981—the date of Monique's first carnet—and ending in 1996. The sequencing of the photographs also reproduces, with one or two exceptions, the linear trajectory of the passage of time. In the first, Monique Sindler is two or three years old; in the next she is a young teenager; in those that follow a young woman. The visible signs of Monique's ageing are matched by the signs of technological development that mark the progression of the history of photography - the passage, for example, from 
black and white to colour. Together then, the sequencing of both photographs and diary entries inch the reader-viewer progressively closer to the three photographic stills in the centre of the book.

But what is it that these stills represent? Had Calle merely displayed one photograph-the first, in which her mother lies peacefully, in classic deathbed pose-one might say that the diary entries and photographs do indeed count down the moments of a life, to death. But after the first photograph, another has been placed, in which the hand rests on the side of Monique's face and then a third, in which the hand appears in front of the mouth. This staggered end undermines the incremental precision by which countdowns operate; it also blunts their point. This obliges us to return to the beginning of the book, and to read and look again. This time, we are struck not only by what we read and see but also by how we do so. We now recognise our own hand in the process of reading. The visual prominence of the hand in the stills stimulates an awareness of our own, and of the fact that it too has reached across the page, as our eyes have scanned the diary writing, or rested on the photographs. The diary is first introduced to the reader not as text, but as photographed object. Each of these photographs has been carefully aligned such that the spine of the diary in the photograph coincides with the spine of Calle's book. This creates the fleeting illusion that to turn the pages of the photo book is to turn the pages of the diary. Shadowing occurs along the right side and lower edge of the photographed notebooks, creating the visual illusion of three dimensionality. Tactility is further reinforced by the fact that the top right hand corner of one of the pages is folded over masking the writing beneath it and triggering a desire in any reader who has worked with manuscripts to reach across and smooth the page back.

The urge to touch is overwhelming. As one reaches across the page, one cannot now not see oneself touching, not see our own hand. Nor can we fail to see the visible markers of age upon it, particularly when we read the diary entry in which Monique writes of visiting her own mother's body in hospital the day after her death:

“1986
28.12
Visite à l'hôpital où ma mère repose sur son lit, sereine.. at last. On a
l'impression qu'elle pourrait se réveiller à chaque moment. Mon frère est
très ému. Les mains de ma mère (plus belles et plus jeunes que les miennes)
sont glacées. Son front aussi depuis hier est glacé maintenant." (Calle n.p.) ${ }^{19}$

Hands, as Monique's insistence on the youth and beauty of her mother's reminds us, are, along with the neck, those parts of the female body which, it is said, display the signs of age most visibly and most quickly. 


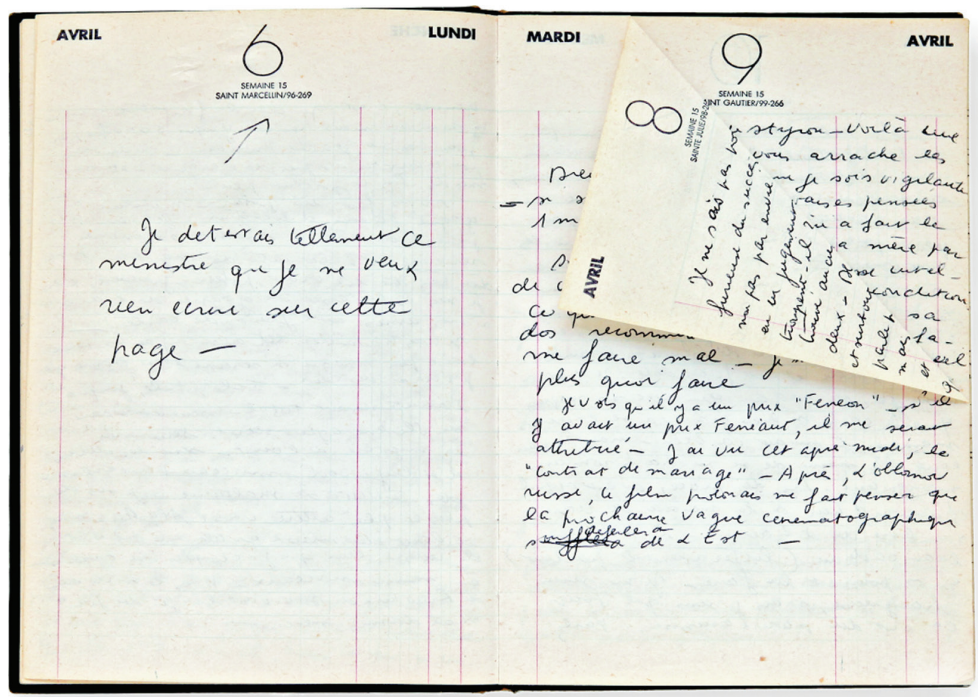

(C) Sophie Calle/Éditions Xavier Barral20

Here, the semiotic and the sensory work together to perform the function of the memento mori.

Our hand has in fact played a part in reading from the first page of the book. On it, or rather, engraved into it, is the text in which Calle explains the circumstances of filming her mother and her mother's reaction to the camera. Linguistically, the text positions the book as driven by the mother's desire to enter the daughter's exhibitive space as the focus of it. Materially, it prepares us - as would-be readers - to use both our fingers and our eyes with what follows. The letters of the words are large; they appear initially as if they are printed in shades of white. Each letter has an edge of shadow to it which initially gives the impression that a particular font and printing technique have been used to create an illusion of three-dimensionality, but that the page is flat and smooth. Depending on the direction of the light, the letters are difficult to read. As we tip the book this way and that to enhance legibility, we begin to suspect that the shadow is created by grooves. This suspicion can only be confirmed by touch. At this point, the words of the bereaved daughter are made palpable: they are tactilely confirmed as a series of impressions on, and into, the expanse of white page. For me, it is difficult to feel and see the indentation of white on white without remembering another element of 
Emma Wilson's description of what happens when she watches the video for the first time in 2007: "Gazing at the video images, touching them with our eyes in a haptic appreciation of what they render present for us, we feel the weight of Monique's head indenting the propped pillow, the clean, ironed fabric of the bedding [...]." (Wilson 2011, p. 180). Wilson is touched emotionally by what she sees, and what she sees is the making of an impression. Etymologically, the English word "intimate" derives from the Latin intimare, meaning to put or bring into, to impress, to make familiar. The sight of the impression made by Monique's head touches Wilson figuratively. Feeling with our fingers the pages of lettering enables us to see their outlines as impressions. Seeing is enabled by touch, touch by seeing; the photo book enacts the mechanics of intimacy.

Clearly then, in the end, a lens has been turned not only on the mother's face, but also on her hand-Monique's cursive script fills the eight pages of the carnet made photographically available to us. However, whether it was Calle herself who photographed the open carnet of her mother's diary is uncertain. She has stated that the process of selecting extracts for publication was performed not by her, but by one of her mother's close friends at her request. The photo book as a whole is dedicated to twelve of Monique's female friends. The sequence of diary extracts and photographs in the first half of the book is the product of collaborative, not individual, engagement with the diaries and albums. The way in which the two are woven together is not unlike the braiding and twisting involved in the crafting of hair jewellery. This sequence can itself be seen as an object of mourning, the making of which contributes to the construction of Monique's posthumous image and, in the process, reworks the daughter's relationship with her mother's friends in-and throughthe absence of the mother herself.

While then the production of the photo book certainly entailed familiarity on Calle's part with certain of her mother's diary entries, it did not necessitate engagement with the diary as a whole. This, Calle has stated in interviews, is precisely what, by July 2012, she had yet to do. In the years following her mother's death, she found herself unable to read the diaries at all: "I could not read it when she was dying. Then she was dead, and the idea was too painful-you know, your mother just died, you don't go back home to read 16 books about her life. Also, I knew there was a big probability that those diaries would be very tough on me and on the world" (Julavits 2014). Elsewhere, she describes her reluctance as fear: "J'avais peur de découvrir son contenu." (Guillot 2012). At stake in Calle's reading of the diaries is not only Monique's perceived vulnerability, but also Calle's own. How intimately she can engage with her mother's diaries is for her, as for Bergman Senior with his wife's diaries, the question that underpins her handling of them. However, whereas Bergman, by taking 
up the magnifying glass, seeks simply to increase intimacy, the question for Calle takes on a different hue. Just how intimately can she engage with her mother's diaries without losing her sense of self? When exercised forcefully on a living surface, impression hurts. It leaves traces that do not disappear immediately. To read the diaries from start to finish, to immerse herself in them entirely is, for Calle, to expose herself to pain. She thus decides to experiment with the means and modalities of engagement. Never having read Monique's diaries in full, she decides to do so, from one end of the sixteen carnets to the other, as an element of the Avignon iteration of the "Rachel, Monique" installation held in the Cloitre des Célestins. Her rules of engagement: there will be no pre-set times for readings. She will enter the Cloitre and read when, and for as long as, she desires-or is able-to do so. One constraint: to finish reading all sixteen carnets before the end of the Festival.

Photographs show Calle sitting on a chair in an alcove of the Cloitre, legs demurely crossed, a notebook in hand, her eyes bent upon it. To the left is a framed chalkboard on which the year of the diary notebook being read, is inscribed vertically. The board's frame and the vertical alignment of the numbers evoke hymn boards. To the right, is an official-looking plaque which informs visitors in capital letters that "Le son est ailleurs." ${ }^{21}$

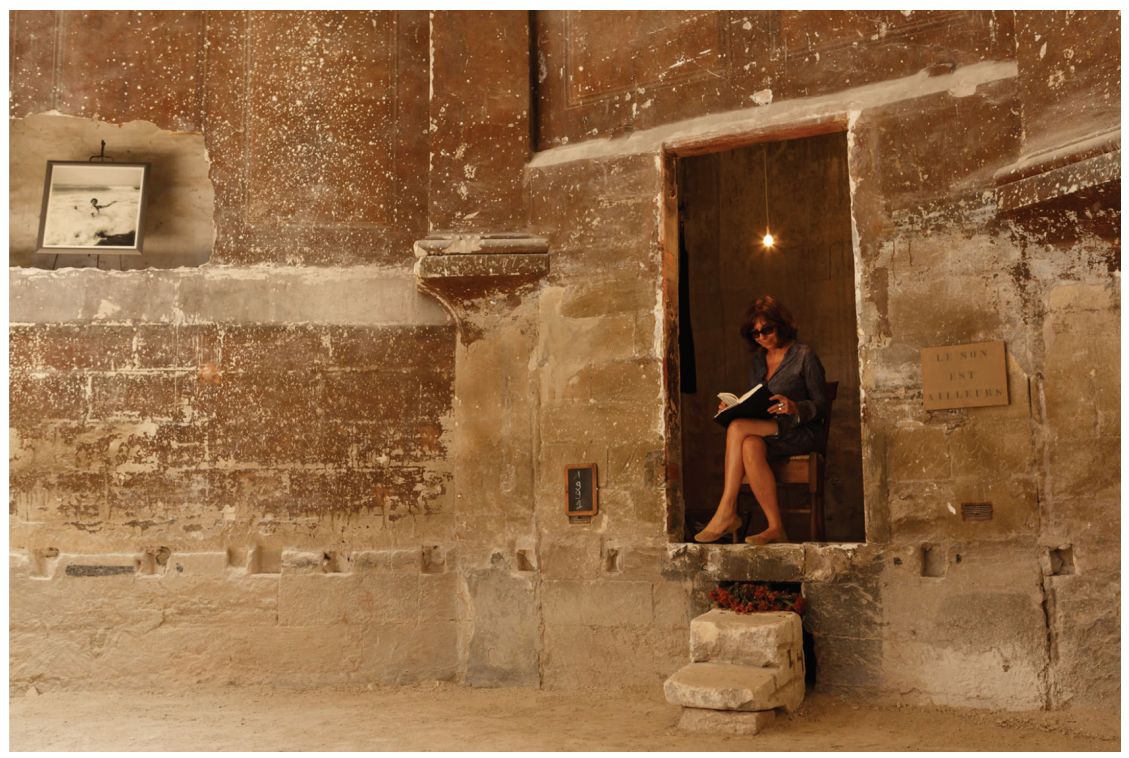

Copyright (C) Christophe Raynaud de Lage ${ }^{22}$ 
Sound does not travel to the spectator; the spectator must travel to it. The visitor who obediently does so, locating it in the form of speakers situated in a corner of the church, then discovers that any view of Calle is now obscured (see Guillot 2012). Calle has stated in interviews that her positioning of the speakers was a deliberate ploy. Well aware that strong emotion configures the face, she no more desired that her reading of her mother's diaries turn her own face into spectacle than she desired to see visitors' features arranged into airs of expectancy. Should she wish to stop reading she does not, she states, want to feel compelled to continue by the postures and expressions of visitors aligned before her. In short, Calle's displacement of sound seeks to prevent a physical proximity that, given the nature of the material she will be reading and the lack of theatrical fixtures such as seating, risks tipping over into promiscuity. To be promiscuous is to be indiscriminate: the term comes from the Latin promiscuus, based on the verb miscere. By locating the speakers in a distant corner of the Cloître, Calle unmixes sight and sound, separating them out as distinct sensory components of display, and forcing the visitor to make a choice: either s/he or moves closer to the speakers, or s/he stays momentarily put before moving on elsewhere.

To elect to move closer to the speakers is to be propelled by a desire to know what Monique had to say in the diaries about herself, her lovers, her famous daughter and her equally celebrated literary acquaintances. To be visually deprived of the scene of diary reading once one arrives at the speakers is to become conscious of hearing and what it affords in ways that one was not before. One begins to hear not only the words uttered, but their vocal materialisation: the grain of Calle's voice, its cadences and inflections, its catches and breaks. Given that what one now sees no longer works with what one hears and can therefore only function as a distraction from it, one seeks to sharpen auditive focus by eliminating the visual, closing one's eyes or lowering the head. This is the posture of prayer.

To stay put at the alcove is to be unmoved by curiosity concerning the contents of Monique's diary. It is also to interpret the sign not as an imperative to seek out sound, but simply as an invitation to stop straining one's ears, to take a step or two back and begin using one's eyes instead. As one shifts backwards, the alcove as a whole emerges into the field of vision. Calle and the diaries are, we now realise, framed by it in much the same manner as the bodies of plaster saints_or indeed, of the Madonna. We now note the blue of Calle's dress, the single bright light that shines directly above her head, the resting of the diary on her knee. This is a Madonna and child in reverse: as the former clasps the body of her son, so now the adult daughter holds the carnet of her mother. This visual 
clin d'œil is extended by what one reviewer has described as a glass coffin that lies at Calle's feet. Within it lie all of Monique's remaining diary notebooks. Depending on timing, the visitor may see Calle removing a notebook from it, or putting the one she is reading to rest inside it. I read this mise en scène as an elaborate parody not only of the particular contribution made by Catholicism to Western cultural representations of motherhood, but more pointedly, of the trope that has over the decades surfaced most consistently in writing about reading women's diaries. Historians and literary scholars alike have attempted to make sense of their archival encounters with diaries by casting their research as a means of resuscitating previously stifled feminine voices and allowing them to be heard. The Sleeping Beauty metaphor is, within such writing, particularly pervasive. ${ }^{23}$

However, Calle does not remain in her alcove. Asked by the American novelist Heidi Julavits whether reading her mother's diaries in public was "a way for [her] to feel safer somehow" Calle responds as follows: "It was the only way, because otherwise I would skip pages when it was boring. It was the only way to read them with a certain obligation. You cannot stand up, make tea, answer the phone..." (Julavits 2014). Clearly, it is not only the prospect of pain that has prevented Calle from reading the diaries in full, but also that of boredom. Equally clearly, what draws her to the diaries is not only that very peculiar form of attraction that is also a form of dread, in which the desire to know is matched in intensity by the fear of it, but also a strong sense of filial obligation. Calle, it seems, has interpreted her mother's handing over of the diaries to her as a moral injunction to read, and to read thoroughly. ${ }^{24}$ One notes that what Calle has to say about reading in public here presupposes the very airs of expectancy that, elsewhere, she has pointed to as potentially irksome. She requires of the installative situation both that it allow her to stop reading when she is physically or emotionally unable to continue, and that it require her to keep reading when she no longer feels inclined to do so. Depending on the nature of the passages being read, she needs now for visitors to keep their place, now that they keep her, and the diaries, in theirs. Of interest here is not how successful Calle is in drawing on the installative space as a means of managing both pain and boredom, but the effects on this space of her use of it. Whereas weeping immobilises Calle, boredom spurs her into movement. The prosaicness of certain everyday details-what Monique made for dinner for example-propels her out of the alcove and into the main body of the church, a small microphone attached to her person. This, judging from a photograph in the Festival d'Avignon's digital archives, seems to have had the effect of stilling visitors, of stopping them in their tracks. 


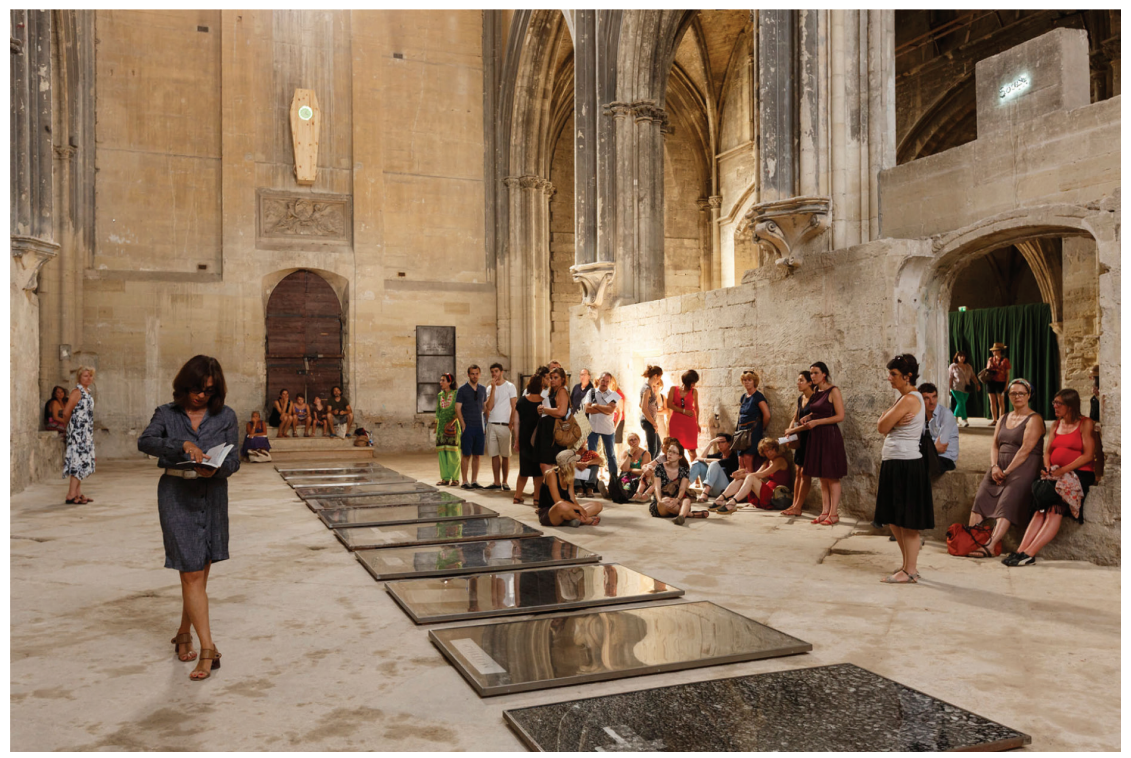

Copyright (C) Christophe Raynaud de Lage ${ }^{25}$

The photograph shows Calle walking the length of the church, to one side of a series of black and white photographic reproductions of tombstones set on the ground. The majority of visitors either stand or sit on the other side of the mortuary slabs. Clustered together in groups, they are stationery. Calle's movement has clearly arrested their own. They sit, stand or perch where they can. Propped against the wall, their motionless bodies run the length of it, giving them the appearance of exhibits. The sequencing of stillness and movement is as much a component of this installative space as it is of the video footage.

The particular ways in which Calle draws on the materiality of the photo book makes of it not a mere supplement to the 2012 installation, but an active participant in the extension and development of meanings produced by it. The book is covered in a white material which scintillates in the light. Along its spine and on its front cover, large lettering has been embroidered in gold thread. The book's ornateness, its heft and solidity, evokes those books that are also objects of piety-communion missals and prayer books. As such, it points forward in time to Calle's 2014 installation "Rachel, Monique" in the Church of the Heavenly Rest in New York. Reviews note that visitors sitting in the pews of the church 
discover in the racks before them not prayer books, but "the bound volumes of Mme Sindler's selected diaries" (Stein 2014). ${ }^{26}$ As they sit, they hear a female voice on audio loop, broadcast from speakers in the chapel choir, reading from the diary. The voice belongs to Kim Cattrall. Calle thus pays homage to her mother's fondness for the character played by Cattrall in the long-running American series Sex and the City, even as she continues, this time in auditive form, her parody of the fantasies peddled by fictional representations of women's diaries as source of revelation of the workings of female sexual desire. Humour, of course, is also a form of distancing. It too has its place in an exploration of the limits and conditions of intimate engagement.

In summary, it is the triple status of the diaries as personal possession, practice and text that, in conjunction with the status of Calle's relationship with her mother, makes of them particularly potent objects in the aftermath of death. The affective clout exercised by the visible traces of the body of labour on the page-the indentations left by the nib of the pen-intersects with the authority that death attaches to the mother's words to make reading both compelling and dangerous. Just as the manipulation of the video camera constitutes part of the means by which Calle enacts a relationship with her dying mother, so her mother's friendships and the particular kinds of work afforded by the architecture of the photo book constitutes for Calle an initial means of engaging with the diaries. By displaying diary extracts with photographic stills from the video in the book, and by entering with the diaries into the Cloître des Célestins, Calle does not merely draw on the history of the Cloitre as cultural site and that of The Book as object of piety and source of hermeneutical truth as a means of mediating her engagement with the diaries, but makes of that engagement itself a focus of sensory and epistemic inquiry. Inaugurated in 2007 by the display of the video within an installation that was itself part of a wider exhibition entitled "Think with the senses, feel with the mind," the semiotic network into which the diaries enter has been defined from the outset as the means by which the relationship of the senses to knowledge is explored. It is the particular twist given to this exploration by the material specificity of the diaries themselves, the cultural history of the Avignon festival as a forum for theatre and Calle's awareness of the fascination exercised by the Mother's diaries that is significant here. The affect triggered in Calle by her reading of the diaries does not only play out on her face, or in and through her own body, but reconfigures the installative site, redistributing and rearranging visitors' bodies within it, and reversing the subject/object dichotomy on which the epistemic authority of the traditional gallery space depends. 


\section{WORKS CITED}

Bal, Mieke. "Guest Column: Exhibition Practices." PMLA 125.1 (2010): 9-23. Print.

Beattie, Kathryn. "From Private Places to Public Spaces: Mourning and Death in the Art of Four Twenty-First-Century Women." Ed. Maureen Daly Goggin and Beth Fowkes Tobin. Women and the Material Culture of Death. Farnham, Surrey: Ashgate, 2013, 223-236. Print.

Bergman, Ingmar. The Magic Lantern. Trans. Joan Tate. London: Hamish Hamilton, 1988. Print.

Bryson, Norman. Vision and Painting: The Logic of the Gaze. New Haven: Yale UP, 1983. Print.

Calle, Sophie. Elle s'est appelée successivement Rachel, Monique, Szyndler, Calle, Pagliero, Gonthier, Sindler. Ma mère aimait qu'on parle d'elle. Paris: Éditions Xavier Barral, 2012. Print.

Festival d'Avignon, archives 2012, "2012 images.” n.d. Web. 11 Mar. 2016. http://www.festival-avignon.com/en/archives-2012.

Guillot, Claire. "Sophie Calle et sa mère, toute une histoire." Le Monde Blogs 7 July 2012. Web. 11 Mar. 2016. http://expo-photo.blog.lemonde.fr/2012/07/07/sophie-calle-et-sa-meretoute-une-histoire/.

Guillot, Claire. "Sophie Calle, manipulatrice d'émotion." Le Monde Culture 11 July 2012. Web. 11 Mar. 2016. http://www.lemonde.fr/culture/article/2012/07/11/sophie-calle-manipulatrice-d-emotion_1732127_3246.html.

Hallam, Elizabeth, and Jenny Hockey. Death, Memory and Material Culture. Oxford: Berg, 2001. Print.

Hartman, Kabi. "Ideology, Identification and the Construction of the Feminine: Le Journal de Marie Bashkirtseff." The Translator 5.1 (1999): 61-81. Print.

Heinz, E. "New York - Sophie Calle: Rachel, Monique at the Church of the Heavenly Rest through June 25th, 2014." Art Observed. 22 June, 2014. Web. 11 Mar. 2016. http://artobserved.com/2014/06/new-york-sophie-calle-rachel-monique-at-the-church-of-the-heavenly-rest-through-june-25th-2014/.

Julavits, Heidi. “Sophie Calle.” Interview Magazine 19 May 2014. Web. 11 Mar. 2016. http:// www.interviewmagazine.com/art/sophie-calle-1/\#_.

Laugs, Martha. America After Life. Text Daniel Kletke. Munich: Kehayoff, 2000. Print.

Lejeune, Philippe. Le Moi des Demoiselles: Enquête sur le journal de jeune fille. Paris: Seuil, 1993. Print.

Linton-Malmfors, Birgit. Den dubbla verkligheten: Karin och Erik Bergman i dagböcker och brev 1907-1936. [Stockholm]: Carlssons, 1992. Print.

Masschelein, Anneleen. "Capturing the Last Moments: Recording the Dying Body at the Turn of the 21st Century." Image E Narrative 14.3 (2013): 122-140. Print.

Murphy, Sara. "Mourning and Metonymy: Bearing Witness between Women and Generations." Hypatia 19.4 (2004): 144-168. Print.

O'Doherty, Brian. Inside the White Cube: the ideology of the gallery space. Intro. Thomas McEvilley. Santa Monica: Lapis Press, 1986. Print.

Olin, Margaret. Touching Photographs. Chicago: U of Chicago P, 2012. Print.

Rabaté, Jean-Michel. "Kallos Anti-Bathos? (From Calle to Freud, Lacan, and Back)." Ed. Sara Crangle and Peter Nicholls. On Bathos: Literature, Art, Music. London: Continuum, 2010. Print.

Stein, Sadie. "Worry." The Paris Review 14 May, 2014. Web. 11 Mar. 2016. http://www.theparisreview.org/blog/2014/05/14/worry/

The Bridges of Madison County. Dir. Clint Eastwood. Perf. Clint Eastwood and Meryl Streep. Based on novel by Robert James Waller. Warner Bros., 1995. Film. 
Wilson, Emma. "Mortality, Art and Disguise: On Sophie Calle's Pas pu saisir la mort (2007)."

Ed. Manon Mathias, Maria O'Sullivan and Ruth Vorstman. Display and Disguise. Oxford: Peter Lang, 2011, 165-181. Print.

Wilson, Emma. Love, Mortality and the Moving Image. New York: Palgrave Macmillan, 2012.

\section{ABOUT THE AUTHOR}

Sonia Wilson is a Lecturer in the Department of French and Francophone Studies at the University of Sydney. She is the author of Personal Effects: Reading the Journal of Marie Bashkirtseff (Legenda 2010), has published several articles on French women's diary writing and is currently working on a project on the agenda in late nineteenth and early twentieth century France.

\section{NOTES}

1 See among others, Hockey, Jenny, Jeanne Katz and Neil Small, eds. Mourning and Death Ritual. Buckingham: Open University Press, 2001; Hallam, Elizabeth and Jenny Hockey, Death, Memory and Material Culture. Oxford: Berg, 2001; Gibson, Margaret, Objects of the Dead: Mourning and Memory in Everyday Life. Melbourne: Melbourne UP, 2008; Hockey, Jenny, Carol Komaromy and Kate Woodthorpe, eds. The Matter of Death: Space, Place and Materiality. Basingstoke: Palgrave Macmillan, 2010; Buchan, Bruce, Margaret Gibson and David Ellison, "Reflections on the Death Scene." Cultural Studies Review 17.1 (2011): 3-15; Gibson, Margaret, "Death and Grief in the Landscape: Private Memorials in Public Space." Cultural Studies Review 17.1 (2011): 146-161; Ennis, Helen. "Death and Digital Photography" Cultural Studies Review 17.1 (2011): 125-145.

2 This photograph was taken by the German photographer Martha Laugs (Laugs 67).

3 Unable to seize death.

4 Rachel, Monique Palais de Tokyo, 2010; Rachel, Monique Cloître des Célestins, Avignon, 2012; Rachel, Monique The Episcopal Church of Heavenly Rest, New York, 2014.

5 Anneleen Masschelein has positioned the objects displayed in Calle's installative series, and in particular the video that remains a constant throughout them, with respect to the iconographic history of the scene of death and the turn that this is currently being given by the practice of digital photography in general and the phone camera in particular (133). Kathryn Beattie posits a parallel between the crafting of mourning objects by nineteenth century women on one hand, and on the other, the creation by four twenty-first century women artists, one of whom is Calle, of visual objects that bear a relationship to the body of a loved one. Emma Wilson sees Calle's 2007 installation as affording a means of managing, or working with and through, grief. Her analysis of the 2007 installation at the Venice Biennale forms part of a sustained investigation into what Wilson calls "palliative art," defined as "art that examines mortality and that in so doing seeks to explore the possible relief or reprieve fostered through creativity" (165). See also chapter 2, 'Mother', of Wilson's Love, Mortality and the Moving Image 2012.

6 The term 'white cube' was coined by Brian O'Doherty to designate gallery spaces which "subtract [...] from the artwork all cues that interfere with the fact that it is 'art'." Thus walls are painted white, windows are sealed off and uniformity of light is ensured by making the ceiling the only source of illumination (14). Mieke Bal credits exhibitions in the 1980s and 1990s by Rudi Fuchs, Harald Szeeman and Catherine David, among others, 
as replacing the white cube with "something like a Gesammtkunstwerk of a specifically designed combination of artistic objects, sometimes with the building and the spaces therein as active participants". (9). Calle's work can be seen as participating in this wider shift.

7 I am drawing here on Arjun Appadurai's seminal volume The Social Life of Things (1986) and, in particular, on the essay by Igor Kopytoff within it.

8 The packet left by Karin Bergman in the safe deposit box and which contained her diary was addressed to her daughter, Margareta: "Till Margareta efter min död eller att brännas". Birgit Linton-Malmfors, Den dubbla verkligheten, p. 9.

9 The last words spoken before Monique died were "Ne vous faites pas de souci". [Don't worry].

10 Calle, Sophie, Elle s'est appelée successivement Rachel, Monique, Szyndler, Calle, Pagliero, Gonthier, Sindler. Ma mère aimait qu'on parle d'elle. Paris: Xavier Barral, 2012.

"A few days before losing consciousness, my mother asked me to take the box containing her photo albums and diaries. Sixteen notebooks dated 1981, 1984, 1985, 1986, 1987, $1988,1990,1991,1992,1993,1994,1995,1996,1997,1999,2000$. She chose not to destroy them. My mother was not naive concerning what might happen if she left them to me. Otherwise I would never have allowed myself."

This, and all other translations of Calle's writing, are my own unless indicated otherwise.

11 I borrow the term from Norman Bryson, who uses it in his discussion of Chinese painting and deictic reference (88).

12 I wish to thank Sophie Calle and Éditions Xavier Barral for kindly allowing this photograph to be reproduced.

13 "My mother had always planned to go to the North Pole one day. She died two years ago without fulfilling this dream. [...] Invited to travel to the Arctic by ship, I accepted on her behalf. To take her there. I disembarked on the shore. I chose a stone and I buried the portrait, the necklace and the ring. This is how my mother arrived in the Great North."

14 "She chose not to destroy them. My mother was not naive concerning what might happen if she left them to me. Otherwise I would never have allowed myself."

15 "My mother liked being talked about. Her life doesn't appear in my work. That annoyed her. When I set up my camera at the foot of the bed in which she was dying, because I feared that she might pass away in my absence and I wanted to be there to hear her last word, she exclaimed 'Finally'."

16 Anneleen Masschelein refers to both short texts as "hedging remarks" and positions them as part of the means by which Calle "defends her projects" (127).

17 The filmic image is horizontally rectangular in shape, as is deathbed portraiture generally. The camera is placed at the top of the bed, but angled very slightly to the left, such that only Monique's face and upper body appear in the frame. The face is filmed in profile, the eyes closed. The line of the profile is accentuated by the fall of light, which illuminates Monique's forehead, and runs as a thin sliver along the ridge of her nose and her philtrum bathing the curve of her cheek and chin.

18 Even for those unacquainted with the specific conventions of post-mortem photography, the visual metaphor of sleep - enacted by Monique's closed eyes and mouth, her nightdress, the quilt drawn to mid chest - and the flowers are sufficiently familiar as representations of death to suggest that Monique has already expired.

19 "Visit to the hospital where my mother lies on her bed, serene ... at last. One has the impression she could wake up at any moment. My brother is very moved. My mother's hands (more beautiful and younger than mine) are cold. Her forehead also, since yesterday, is cold now".

20 I wish to thank Sophie Calle and Éditions Xavier Barral for their kind permission to reproduce this photograph. 
21 The sound is elsewhere.

22 Photograph reproduced with the kind permission of Christophe Raynaud de Lage.

23 It is to the Sleeping Beauty story that Philippe Lejeune turns, tongue in cheek, when, in the early stages of his research, he seeks to make sense of his interaction with the late nineteenth century journaux de jeunes filles upon which he stumbles in archives and flea markets: "Je me vois donc plutôt, tant pis pour le ridicule, Prince Charmant allant réveiller des Belles au Bois Dormant" (43). Kabi Hartman has identified "an unacknowledged but pervasive rescue narrative" at work within commentary on Marie Bashkirtseff's diary. This leads, she notes, to a collective personification of the Journal as a kind of Sleeping Beauty (65).

24 Calle's apparent interpretation of her mother's handing on of the diaries as an injunction to read resonates with other elements of the installative series. The obituary published in Libération and displayed in every iteration of the installation since 2007 makes it clear that the daughter scrupulously carried out every last wish of the mother before and after she died, taking her for a last trip to the seaside and burying her with the clothes and shoes she selected. As noted above, the burial of the mother's necklace, ring and photographic portrait in the Arctic is also represented as a means of fulfilling a desire articulated by the mother. Of particular relevance here is Jean-Michel Rabaté's reading of Calle's installation Je n'ai pas pu saisir la mort in the 2007 Venice Biennale as a response to the mother's words. Calle received the invitation to represent France at the Biennale only minutes before a second telephone call, in which she learned of her mother's imminent death. When her mother articulated her disappointment that she would be unable to attend the Biennale, Calle assured her that she would be present. Rabaté reads Calle's 2007 installation as a gesture comparable to that of Antigone: she takes her mother's observation that death will prevent her from attending Calle's exhibition at the Venice Biennale as "an injunction against which [Calle as] daughter had to fight", ensuring her mother's presence at the Biennale despite-and in the face of - the "unwritten law of common propriety" (175). For a thought-provoking and insightful analysis of other ways in which the self-representation of the daughter is bound up with "an obligation to a mother," see Sara Murphy, "Mourning and Metonymy: Bearing Witness Between Women and Generations." p. 147.

25 Photograph reproduced with the kind permission of Christophe Raynaud de Lage.

26 See also Heinz, "Sophie Calle: Rachel, Monique at the Church of the Heavenly Rest through June 25th, 2014". 